Acta vet. scand. $1960,1,201-220$.

From the Department of Bacteriology and Hygiene, The Veterinary College of Norway, Oslo.

\title{
BOVINE MYCOTIC MASTITIS
}

By

G. Loftsgård and K. Lindqvist.

In recent years numerous reports have appeared concerning fungous infections in man (37) (19) and in animals (24) (27) following administration of antibiotics. In many cases such induced fungous infections have been the actual cause of death (5) (40). Bovine mastitis has for a number of years been treated with antibiotics. On this basis it would be reasonable to expect an increase in frequency of mastitis caused by fungi; and, in fact, the number of reports on mycotic mastitis from laboratories working in this field has increased during recent years. We feel that the cases of mycotic mastitis are becoming a problem to workers in bovine mastitis, a problem deserving more attention than has hitherto been paid to it.

Consequently, we shall give here a survey of the literature pertaining to this subject, limiting our discussion to the most important agents, the yeasts. In addition we shall describe 7 cases of udder infections caused by fungi. Finally, certain features in the evaluation of the mycological findings will be discussed.

\section{A REVIEW OF THE LITERATURE}

As early as in 1901 Klein (18) reported the isolation of pathogenic yeasts from a sample of pooled milk. From his description, there is little doubt that the organism concerned was a strain of Cryptococcus neoformans. As to the origin of the agent, no opinion was expressed.

During a study of the udder flora of cows by Harding and Wilson (12) in 1913, unidentified yeasts were found to be constantly present in one udder. The organisms were considered to be undoubted members of the normal udder flora.

In a report on acute mastitis in 1931, Klimmer (20) mentioned the isolation of yeasts from a case of mastitis in a cow. 
The first more detailed record of yeasts isolated from cases of actual bovine udder inflammation, was that of Rolle (30) in 1934. His observations concerned 5 cases from which he isolated in pure culture yeasts which he regarded as identical and resembling bakers yeast. Local and general symptoms similar to those occuring in the natural outbreak followed the inoculation of the udder of a normal cow with the isolated yeast strain.

Since the introduction of antibiotics in the therapy of the bovine udder there has been a remarkable increase in the number of published observations on mastitis caused by fungi. In 1947 Murphy and Drake (25) reported 10 cases of infections with yeast-like fungi in a herd of 12 cows. The yeasts were identified as a species of Trichosporon. 6 of the cases showed obvious swelling of the glands for 2 to 7 days. Macroscopic abnormalities of the secretion were present from 3 to 12 days in all cases but one. The infections lasted from 6 to 48 days. The investigators succeeded in reproducing the condition by inoculation of the udder with mastitis secretions.

The first report on mycotic mastitis following udder therapy with contaminated preparations of antibiotics was published in 1947 by Lernau, Shapiro and Aschner (22). Severe mastitis was observed in 17 out of 34 cows which had been treated with penicillin. The yeasts cultured from the inflamed udder were identified as Pichia farinosa. The same species was also isolated from the penicillin solution.

During routine biological examination of pooled milk for tubercle bacilli, Carter and Young (6) in 1950 isolated a strain of Cryptococcus neoformans. None of the cows in the sampled herd showed clinical signs of disease.

Andersen and Jorgensen (2) in 1949 found yeast cells of the family Torulaceae from 14 quarters showing symptoms of acute mastitis, after penicillin medication for chronic streptococcus infection. They found that the distilled water used to dissolve the penicillin had become infected with yeasts. The clinical symptoms were limited to a few days. After 6 weeks yeasts could no longer be cultivated from the milk.

A similar report by Stuart (36) in 1951 was concerned with the outbreak of mastitis in 11 out of 26 cows having been treated with penicillin infusions of the udder. The isolated yeasts belonged to the genus Candida, but differed from $C$. albicans. He was able to reproduce the condition experimentally by the infusion of mastitis secretions and chicken embryo cultures from the milk, but not with glucose broth cultures of the yeast.

Hulse (14) in 1952 reported another case, in which the infected cows had been fed with brewers grains. The condition was reproduced experimentally by the injection of penicillin artifically contaminated with the cultured yeast.

A severe mastitis problem in a large dairy herd was discussed in a publication in 1952 by Ponden et al. (26). Out of 235 cows, 106 had become infected with Cryptococcus neoformans during a period 
of one year. 55 of them showed clinical symptoms varying from slight abnormalities of the milk to very severe attacks. The origin of the infection could not be determined. The distinct and characteristic udder lesions in this outbreak were thoroughly described in a paper appearing the same year by Innes et al. (16). They found the infection usually confined to the udder and the supramammary lymph nodes. In one case, however, the lungs were observed to be the site of minute lesions, which were thought to be of metastatic origin. The identification of the strains from this same outbreak was carried out by Emmons (8). The bovine strains were also compared with strains from human cryptococcosis and from soil. Attempts to isolate the organism from the environment of the cows were fruitless.

Another outbreak of cryptococcosis of the bovine udder was reported by Simon et al. (34) in 1953. The administration of antibiotics without regard for aseptic technique was considered to be the source of the disease. The ineffectivity of the usual antibiotics against cryptococcosis was also demonstrated.

Tucker (40) in 1953 observed several cases, both natural infections not associated with udder treatment and infections known to have followed medication.

The same year Steele-Bodger (35) reported the isolation of unidentified yeasts from 17 cases of mastitis, some of which were mixed infections with bacteria.

The absence of aseptic technique in penicillin treatment of Streptococcus agalactiae infections was also the source of 2 outbreaks of yeast mastitis in 35 cows, decribed in 1954 by Galli (9). In the first outbreak in which "Debaryomyces neoformans" (Cryptococcus neoformans) was found to be causative agent, 26 cows in a herd of 62 were so severely affected that they were judged incurable and sold for slaughter. In the second, which was caused by Candida pelliculosa, 9 out of 32 cows became infected; this infection, however, ran a mild course.

The same year, Simon and Hall (33) reported the isolation of species of the genus Candida from an outbreak of mastitis associated with dry storage of teat cups.

In a report from a collective mastitis campaign, Hovmand et al. (13) in 1955 described yeast mastitis in 12 cases in 4 herds. The cows had all been treated with penicillin, but the infection was not attributable to the penicillin tubes, and its source could not be traced. The causative organisms in all cases were identified as Candida species.

In 1955 Seele and Lauer (31) isolated an unidentified yeast from a case of acute mastitis resistant to antibiotic therapy.

In the same year Trujillo et al. (38) reported 2 cases of yeast mastitis. Proper typing of the strains was not performed.

Kauker (17) published data in 1955 concerning 7 different yeast strains isolated from abnormal milk samples during a 3 year period. 4 of the strains were identified as species of Candida, the others were 
Saccharomyces fragilis and Hansenula anomala. A description was given of the clinical aspect of the disease. Furthermore, the resistance of the yeast strains towards antibiotics was determined and inoculations in laboratory animals were tried. The possibility of penicillin treatment as a factor predisposing to yeast infections was also investigated.

Ainsworth and Austwick (1) reported in 1955 the finding of 35 species of fungi from mastitis milk. Among the isolated species, only Pichia farinosa had earlier been considered a cause of mastitis. Candida krusei was found to be incriminated in 3 cases of penicillinresistant mastitis.

Gerigh (10) in 1955 found no yeasts during his large scale examinations of 1656 milk samples from inflamed and from healthy quarters. Using teat impressions on agar, however, he detected yeasts in 3 out of 38 animals examined; in 2 of them Torulopsis famata and in the third Candida krusei were found.

A recent case of udder cryptococcosis was reported in 1956 by Segretain et al. (32).

In 1957 Redaelli (29) published data concerning artificial inoculation of goats and cows with strains of Candida, Torulopsis, Saccharomyces, Pichia and Hansenula, all of which were isolated from morbid udders of cows. In another paper (28) in the same year, he demonstrated that strains of Cryptococcus neoformans isolated from acute bovine mastitis as well as strains of human origin were pathogenic for animals. The results of these experiments suggested a sharp clinical and pathological distinction of the udder cryptococcosis from infections by other types of fungi because of the lower virulence of the latter. Observations were also made on the influence exerted by antibiotics on the invasive power and growth rate of certain yeast strains.

Another report, in 1957, by Beck (4), dealt with more than 20 cows with yeast infections of the udder, the agents of which were all species of the genus Candida. In the majority of these cases, previous medication with antibiotics was considered to be of importance in the development of the condition. Experimental infection of cows using broth cultures of the isolated agents could not be established.

The foregoing brief review provides the background for our own investigations, an account of which follows.

\section{ORIGINAL OBSERVATIONS \\ MATERIAL AND METHODS}

The material consisted of 1460 milk samples, 980 of which were from clinically healthy quarters, The remaining 480 from cases with symptoms of mastitis varying from slight abnormalities of secretion to ultimate death. The samples were forwarded by veterinary surgeons in the Oslo area and from various departments of the Veterinary College. In addition to the routine 
bacteriological examination, special emphasis was laid on the occurrence of fungi. Information concerning 2 cases (cases 2 and 5) as well as isolates of the causative organisms were kindly put at our disposal by workers at the mastitis laboratories in stavanger and Trondheim. The mycological examination of milk samples was made by plating sediments on Sabouraud's $2 \%$ glucose agar to which had been added 20 units of penicillin plus 40 units of streptomycin per ml. Incubation was carried out at $37^{\circ}$ and $25^{\circ} \mathrm{C}$. The plates were kept for about 3 weeks before being discarded as negative. Further pure culture studies and identification of the yeasts were done according to the methods used by Lodder and Kreger-van Rij. (23).

\section{RESULTS}

During the routine search for fungi in the 1460 samples, massive growth of yeasts occurred only 5 times (cases 1, $3,4,6$ and 7). 4 more samples yielded scant growth of yeasts but repeated samples were negative; in addition, no symptoms of mastitis were present in these 4 cases. Occasionally, milk samples have yielded single yeast colonies, mold colonies (mostly Penicillium and Aspergillus species) or mixed growth of various bacteria and fungi. Considering the scant growth, absence of clinical symptoms of mastitis and the negative results of repeated sampling, such colonies have been regarded as due to contamination.

\section{Field case no. 1.}

From a small dairy herd near Oslo a milk sample was delivered for examination with the following history:

An 8 years old red poll had been in the farmer's possession for 2 years, during which time the cow had not been exposed to treatment with antibiotics. Having calved one month previously she now had a milk yield of $25 \mathrm{~kg}$ a day. On the day before the first sampling, the cow showed complete anorexia, did not ruminate and had a very distinct decrease in milk production. The pulse rate was $\mathbf{1 0 0}$ and pyrexia was present. One gland was warm, hard and definitely swollen. After 2 more days the general symptoms subsided leaving the quarter swollen with abnormal secretions for some 8 days. The secretion on the day of the first sampling was greyish, with a few tiny yellow clots. The volume of sediment after centrifugation was about $10 \%$. Direct microscopy of smears made from the sediment revealed the presence of Gram-positive, comparatively large, oval organisms among a great number of leucoeyte and cell debris (Fig. 1). Some of the organisms showed budding. The first sample as well as 


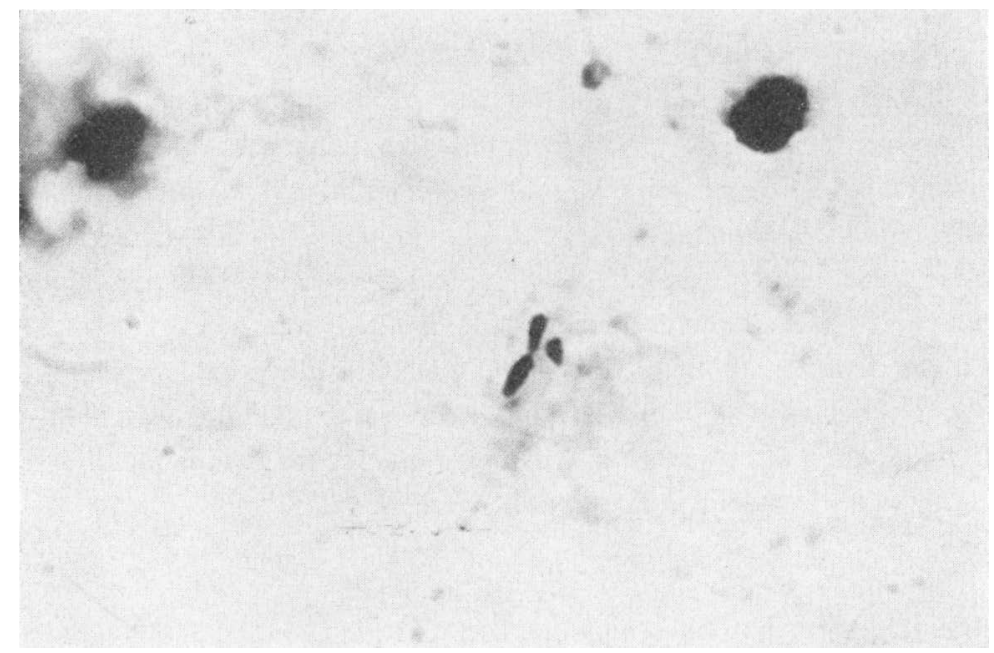

F i g. 1. Gramstained smear from case no. 1. $(1000 \times)$.

repeated ones after $2,3,4$ and 7 days all yielded growth of yeasts which were identified as Saccharomyces marxianus. At the time of the first sampling the cow was given intramammary treatment with a mixture of penicillin and streptomycin. The therapy was discontinued as soon as the presence of yeasts was detected. After 10 days no yeast could be cultured. Clinical examination of the udder 4 months later revealed no signs of abnormality. The milk yield was about the same from all quarters and samples proved to be sterile.

\section{Case no. 2.}

A 5 years old cow had suffered a slight teat injury. The cow had calved one month earlier and was among the best milk producers in a herd of 20 . No previous medication with antibiotics was known to have taken place. Following the injury she developed a very acute and severe mastitis with anorexia and fever of $41^{\circ} \mathrm{C}$. The general symptoms lasted for about one week during which time she was unable to get up and developed decubital ulcers and serous polyarthritis. The cow received sulphadimidine intravenously and supportive therapy. The infection, however, spread to the adjacent gland on the same side. As yeasts were found in pure culture from milk samples from both quarters, mammary treatment was tried, using a solution of crystal violet, but with no apparent curative effect. The second quarter infected shed no yeasts after one week. From the first one, however, yeasts could still be cultured 3 weeks after the onset of the disease. At this time the cow was slaughtered because of the severe destruction of the gland tissue. The organism was identified as Saccharomyces fragilis. 
Case no. 3.

Following a small teat lesion, an acute mastitis arose from which no samples had been taken for bacteriological examination. After local treatment with penicillin the symptoms of inflammation disappeared and the condition was considered cured for some weeks. During the next 2 months the distal part of the teat grew hard and thicker acquiring a shape much like that of an electric bulb. The teat became extremely painful though showing no external wounds. Apart from being somewhat atrophic the gland itself revealed no abnormalities to the clinician. 3 milk samples with intervals of 1 week all yielded growth of yeasts, identified as Candida krusei. No bacterial growth was found. Because of the severe thelitis and the difficulty in milking, the cow was slaughtered.

\section{Case no. 4.}

In connection with a chronic "summer wound" close to the teat canal, a cow developed an acute mastitis of one quarter. The milk yielded no growth, probably due to previous use of antibiotics. A penicillin-streptomycin mixture for intramammary application was infused and polyethylene teat cannulas containing neomycin and bacitracin were used on the following days to facilitate milking. 10 days after the acute attack the milk still contained clots and treatment was repeated. A milk sample now gave moderate growth of yeasts in pure culture. The organism was found to be Candida parapsilosis var. intermedia. 2 days later the local symptoms of mastitis increased, but there were no general signs of disease. A terramycinpolymyxin B mixture was applied to the udder. Another sample at this time showed heavy growth of yeasts. In the course of the next week the mastitis symptoms faded, the milk yield returned to normal and repeated samples 2 and 3 weeks after the last treatment proved to be sterile.

\section{Case no. 5.}

A 5 years old cow with a milk yield of $15 \mathrm{~kg}$ a day showed anorexia, a temperature of $41,8^{\circ} \mathrm{C}$ and moderate swelling of one quarter from which the secretion was thin, yellowish and clotty. The cow had not suffered from mastitis before and had not been treated with antibiotics. A penicillin-streptomycin mixture was infused locally. The next day anorexia and pyrexia persisted and an aggravation of the udder symptoms was noted. From the 3rd day the general condition improved. The quarter, however, had become extremely firm and swollen with sparse amounts of a yellow, watery and clotty secretion. In addition to repeated antibiotic treatment supportive therapy was given. The severity of the local symptoms led to a most unfavourable prognosis as to the future yield of the affected quarter. But 3 weeks later the farmer reported that the cow had recovered completely except for a slight decrease in milk production from the infected gland. The milk sample from the first day of disease gave a 
very rich growth of Saccharomyces fragilis mixed with a few colonies of Staphylococcus aureus. The next sample, taken on the 3rd day, yielded a rich and pure growth of yeast. Another sample 3 weeks later proved to be sterile. After 4 more weeks the now apparently normal udder was again found to be shedding yeasts, but in very moderate numbers. The attending veterinarian noted that the herd had been fed with brewery by-products.

Case no. 6.

In a herd of 12 dairy cows partly fed with brewery by-products, a cow exhibited symptoms resembling those of traumatic peritonitis one week after the 3 rd parturition. The animal had a temperature of $40.6^{\circ}$ and complete anorexia was present. Both left glands showed distinct symptoms of an early mastitis. Local udder treatment with a penicillin-streptomycin mixture seemed to be without effect. The swelling and hardening of the left side of the udder increased during the next days. The fever and anorexia as well as the symptoms of reticulitis faded in the course of the following 5 days. 3 weeks after the beginning of symptoms both quarters had regained normal appearance. Milk samples from the two glands yielded pure cultures of yeasts which proved to be Candida parapsilosis var. intermedia. Quantitative mycological examinations during the first 10 days of the disease revealed an initial number of 800.000 yeast cells $/ \mathrm{ml}$ of secretion, gradually decreasing to $850 \mathrm{cells} / \mathrm{ml}$ on the 10 th day. After 3 weeks samples proved to be sterile.

\section{Case no. 7.}

During a programme to eradicate streptococcal mastitis in a herd of 40 cows, several had been treated with penicillin infusions. 2 days later one of the cows exhibited severe mastitis symptoms with complete anorexia and a temperature of $41^{\circ} \mathrm{C}$. The treated quarter was extremely swollen and hard giving only very small amounts of a serum-like secretion containing a few clots. A sulphadimidine-glucose mixture was given intravenously and terramycin-polymyxin B mixture was infused into the affected quarter. No change for the better was noticed the next 2 days and treatment was continued with sulphadimidine, glucose and a pituitary hormone. As the milk samples yielded massive and pure growth of organisms resembling yeasts (Fig. 2), intramammary administration of nystatin was begun, with $\mathbf{1 0 0 . 0 0 0}$ units in $20 \mathrm{cc}$. of a sterile Seitz-filtered saline solution which had been prepared from a Mycostatin (Squibb) vaginal tablet. The affected quarter received 100.000 units nystatin on each of 4 consecutive days. The 2 last treatments consisted of an unfiltered suspension of Mycostatin vaginal tablets. The quarter remained very hard and swollen for the next week with a very scant and serumlike secretion containing up to $50 \%$ sediment. The general condition of the cow, however, improved greatly during the few hours following the first nystatin treatment; there was a decrease in temperature and a return of appetite. Gradually, the local symptoms of mastitis also 


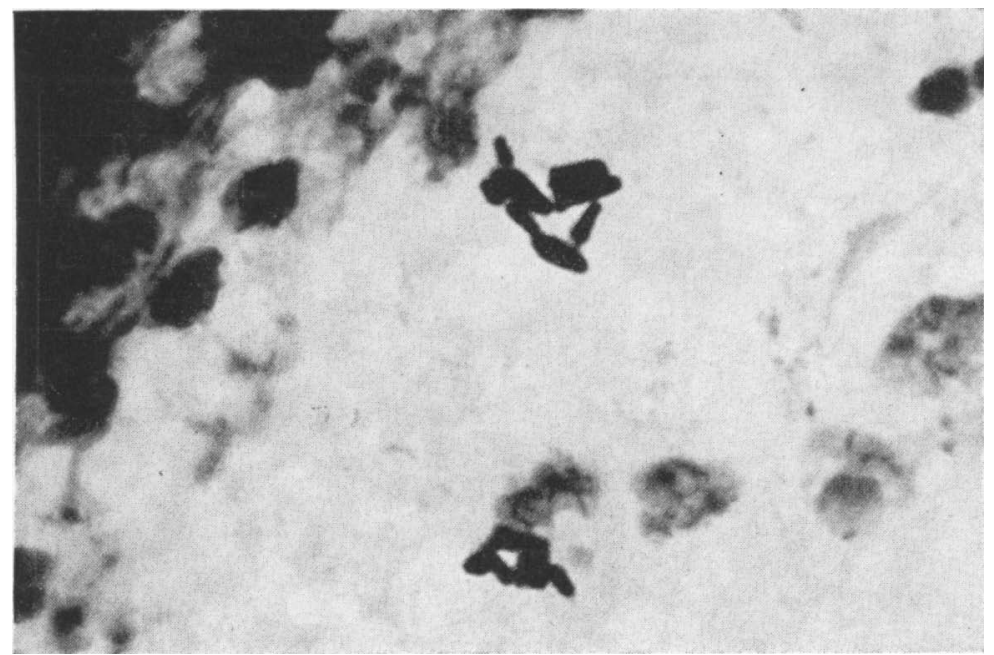

F i g. 2. Gramstained smear from case no. 7. $(1000 \times)$.

subsided, though the agent was still shed. Following an experimental introduction of $0.5 \mathrm{~g}$ terramycin in saline suspension into the affected quarter, no aggravation of symptoms was observed. A very slight but not significant increase in number of shed organisms was registered. From the 17th day after the onset of acute symptoms the still abnormal secretion proved to be sterile. After 4 weeks the milk had regained normal appearance. The exact identification of this organism has not yet been possible. It is assumed that it might be a Trichosporon species.

\section{Growth}

It is obvious on the basis of the biochemical reactions and morphological appearance of the colonies and cells that $S$. marxianus and our strains of $S$. fragilis are closely related. The only difference observed is a slow fermentation of lactose by $S$. fragilis.

As routine bacteriological examination of mastitis samples usually are carried out using blood agar plates, a comparison of the growth on such a medium with that on Sabouraud agar might be of interest. As an example the strain from case No. 1, Saccharomyces marxianus, will be described in some detail:

On blood agar no growth could be seen after 18 hours incubation at $37^{\circ} \mathrm{C}$. After 24 hours colonies of pinpoint size could be detected with some difficulty. After 48 hours these colonies were still less than $1 \mathrm{~mm}$ in diameter. Apart from the smaller size the 
Essential characteristics of the causative organisms.

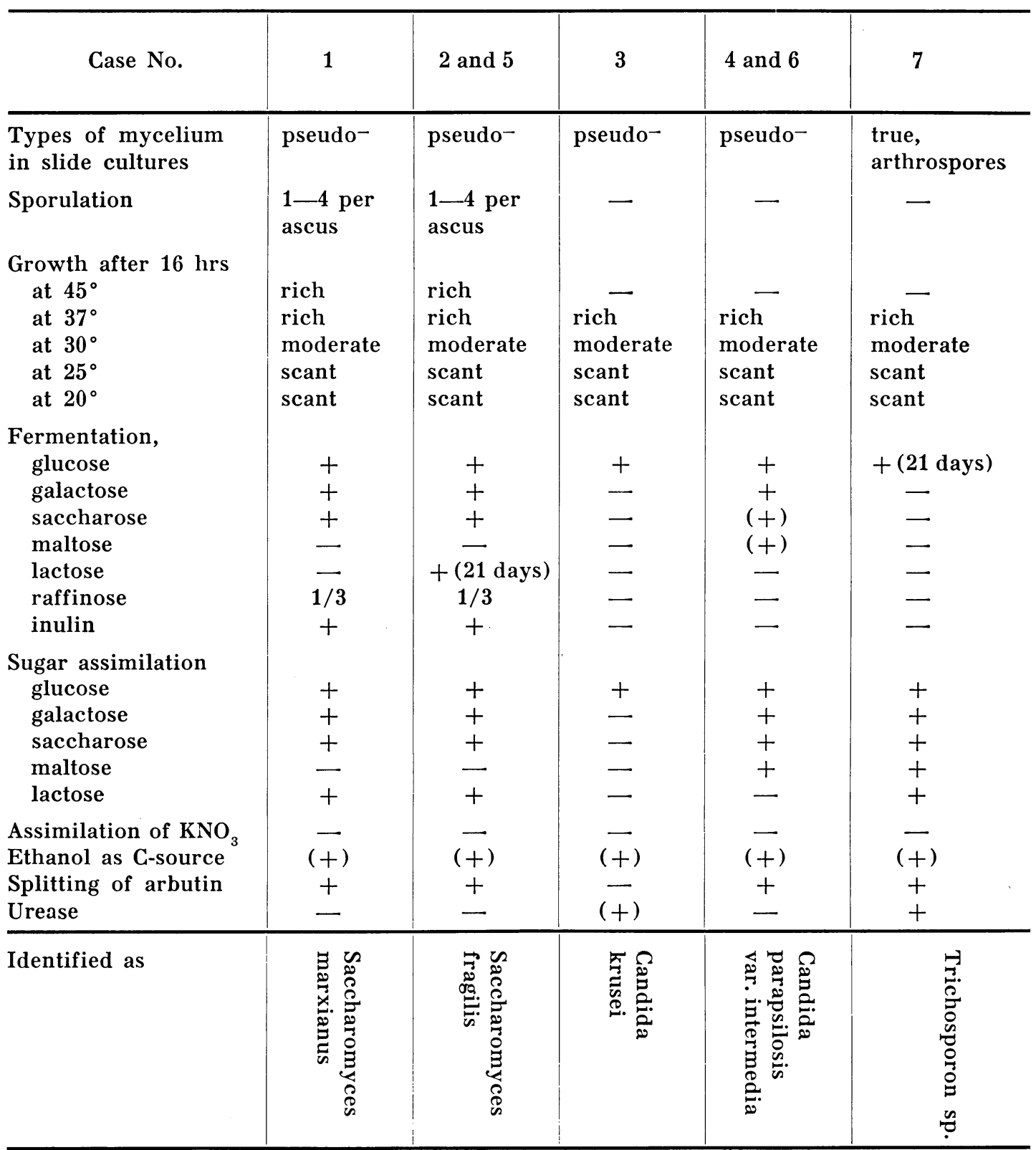


colonies had some resemblance to white, non-hemolytic staphylococci of the same age. On Sabouraud's agar after 18 hours at $37^{\circ} \mathrm{C}$ there was a heavy growth of white, round and convex colonies with a maximum diameter of about $2 \mathrm{~mm}$. A strong odour of yeast and fruity ethers was noticed. The colonies were round, smooth and creamy with entire edges, and were easily suspended in water forming a homogenous suspension. At $25^{\circ} \mathrm{C}$ less abundant growth was observed. As the culture aged, the colonies became surrounded by a fringe consisting of pseudomycelial cells and the colonies attained a diameter of about 5-7 $\mathrm{mm}$ in 2 weeks time. Microscopically the colony consisted of Gram positive long-oval cells. Budding cells and pseudomycelial cells were frequently observed.

\section{Sensitivity tests}

In order to obtain information about the action of antibiotics upon the isolated strains, in vitro tests were performed using sensitivity tablets and filter paper discs on plates of Sabouraud's agar. Penicillin, streptomycin, chloramphenicol, erythromycin, aureomycin and terramycin showed no activity against the fungi. The tetracyclines, on the contrary, had a pronounced growthpromoting effect on all species examined, most distinct around the terramycin discs. Neomycin seemed to have some inhibitory effect on all species except Candida krusei. Polymyxin B, nystatin and trichamycin produced distinct zones of inhibition.

\section{GENERAL DISCUSSION}

The literature of mycotic mastitis clearly demonstrates the rich variety of agents incriminated. This is in accordance with our own observations where 7 cases yielded growth of 5 different species. The following list of isolated organisms only comprizes the yeasts thus excluding Nocardia, Actinomyces and other agents less frequently encountered.

Candida albicans (4) (17) (29)

\begin{tabular}{|c|c|}
\hline & krusei (1) (17) (Ingram i \\
\hline & membranaefaciens (17) (29) \\
\hline & parapsilosis var. intermedia \\
\hline & pelliculosa (9) (29) \\
\hline & solani (17) (29) \\
\hline & tropicalis (29) \\
\hline & species unknown (36) (13) (4) \\
\hline
\end{tabular}




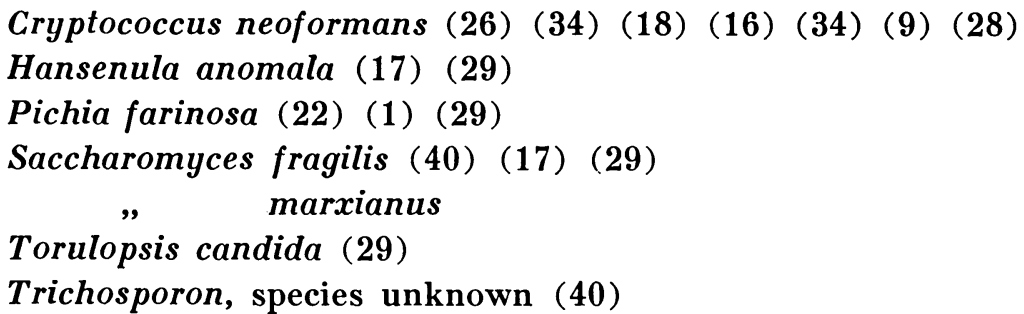

As mentioned earlier there are a great many cases of mycotic mastitis from which the isolated yeasts were not identified. The possibility of other yeast species being associated with mastitis should therefore be emphasized.

Concerning the natural habitats of these yeasts they are all found widely distributed in nature, being ubiquitous saprophytes of plants and plant products. Farm animals, their environment and their food are more or less constantly associated with such fungi. The alimentary canal and the respiratory system are found to be a richer source than the organs of reproduction, the skin or the feces (Ainsworth in 7). Probably they are normal saprophytes on various substrates from which man and animals are infected under certain conditions. There is no reason at present to believe that the yeasts listed above would have special affinity for udder tissue. The rich variety of agents implies that disposition is of a far greater importance for the development of udder mycosis than is the type of agent. Only 2 of the listed species, Candida albicans and Cryptococcus neoformans, have for a long time been considered well-established pathogens for man and animals. The first is the cause of thrush in infants and of thrush-like infections in birds. This agent has also been isolated from cases of systemic infections in cattle (24). The second is the cause of cryptococcosis, in man a chronic, fatal infection with a special affinity for the central nervous system, the skin and the lungs. In farm animals, apart from the numerous cases of bovine udder infections, there have been several reports of pulmonary lesions and generalized infections as well as involvement of the central nervous system (3). There is as yet no evidence that cryptococcosis is contagious or can be transferred to man from infected animals or from dairy products, but there is certainly reason to be observant of the potential danger to public health.

For yeasts, as for bacterial agents of mastitis, the most prob- 
able route of infection is by way of the teat canal. Healthy udders seem rather resistant to mycotic infections as judged by many unsuccessful attempts of reproducing the condition. This is further substantiated by the fact that yeast mastitis generally shows a tendency towards spontanous recovery. On the other hand, several reports, as well as our own observations, demonstrate the potential pathogenicity of many yeast species when they are inoculated into the udder. As in the case of bacterial mastitis, predisposing factors are considered to be of great importance for the establishment of a mycotic infection. Traumatic lesions, and infections affecting the skin of the teat or udder, are surely favourable for the development of an infection. Air inflation of the udder or surgical treatment of the teat might well be disposing factors. The presence of chronic debilitating diseases as predisposing factors to fungous infections, as seen in man, is certainly of less importance in animals.

The numerous reported outbreaks of mycotic mastitis following udder medication with antibiotics clearly demonstrate the hazards involved in such treatment. The use of contaminated preparations in the therapy of bacterial mastitis has been the cause of massive outbreaks of mycotic infections (2) (22) (29). The importance of strict aseptic technique in udder therapy is obvious and should be stressed even when antibiotics are used. The demonstrated possibility of a growth-promoting effect of the common antibiotics on yeasts will be discussed elsewhere. An increase of the environmental yeast flora may, according to some authors (30) (14) (36), cause an increase in the frequency of mycotic mastitis. Attention has been called to the feeding of brewery products in herds where yeast mastitis was found. The mycological findings from the udder, however, have not so far correlated with the results obtained in the examinations of these products (14).

The clinical symptoms of yeast mastitis vary greatly. The majority of the cases are of a mild type, udder and secretion returning to normal after one or two weeks. The agent, however, may on certain occasions be cultured from the milk for several weeks or even months. Cases with increased temperature, anorexia, extreme swelling and hardening of affected quarters and highly abnormal milk are not uncommon, but generally the initial febrile reaction does not last for many days. Infections resulting in death of the animal may occur (40). Most cases 
show no symptoms of general stress after a week, but a lasting decrease in milk production is sometimes observed.

The cryptococcal mastitis often seems to be of a more severe nature than are other yeast infections, for several reports dealing with this type of infection stress the severity of the attacks. The pathological alterations of the attacked glands are extensive, rendering the animals useless for future milk production (26) (16).

In general, however, the yeast mastitis has no specific clinical symptoms that give a clue to accurate diagnosis. Histories of unsuccessful treatment of mastitis, or even intensification of the symptoms, after medication with antibiotics naturally call attention to the possibility of either resistant bacteria or yeasts being the cause. The spontanous cases not associated with previous medication often have nothing in the history, the symptoms nor character of secretions that can help the practitioner. Laboratory examinations are necessary to detect the causative agents. The examination of smears made directly from the milk sample will often reveal the presence of yeasts; though sometimes yeast cells may be extremely difficult to find in smears, even when present in large numbers in the milk sample. As a rule plating and incubation of the sample on suitable media are very necessary to find out whether yeasts are involved or not (21). The growth of many yeasts on blood agar is so scarce that they are easily overlooked, or confused with milk debris or with bacteria (staphylococci). As for the laboratory diagnosis of bacterial mastitis, the milk sample should be fresh or preserved under conditions not allowing contaminating organisms to multiply.

The ubiquitous occurrence of yeasts is a matter to be borne in mind when evaluating the mycological findings. The growth of very few colonies might be due to contamination, and sampling has to be repeated. It is somewhat striking to observe that our strains isolated from mastitis cases are all able to grow at $37^{\circ} \mathrm{C}$. In fact, the growth is more abundant at $37^{\circ} \mathrm{C}$ than at lower temperatures. This property may be of some use in distinguishing between pathogenic yeasts and nonpathogenic yeasts that do not usually grow at $37^{\circ} \mathrm{C}$. A very distinct characteristic of Saccharomyces marxianus and Saccharomyces fragilis is the ability to grow abundantly in glucose broth at $45^{\circ} \mathrm{C}$.

As to the possibility of yeasts constituting part of the normal udder flora, the reported investigations are rather few (12) (39). 
Of recent investigators, some have found yeasts in normal milk samples and some have not. Here only the recent work of Gerigh (10) needs special mention. In 621 milk samples from clinically healthy udders he found no yeasts, thus concluding that yeasts are normally not found in milk samples provided these are taken with aseptic precautions. These findings conform with our own experiences reported in this paper.

The number of recorded mastitis caused by yeasts has greatly increased since the war. This brings up the question of whether the higher frequency is real, or due to increased skill and improved laboratory techniques besides greater alertness to the condition. Reports from various laboratories working in the field of mastitis generally pay little attention to yeasts as a cause of mastitis. The surveys of mastitis agents mostly reveal no incidence of yeast infections. But the increasing number of samples reported as not yielding mastitis organisms, though collected from cases with clinical diagnosis of mastitis, is a striking feature of these surveys. There is little doubt that the presence of antibiotics is responsible for the lack of growth in many cases. For practical and economic reasons, the use of supplementary culture media and more elaborate techniques in the routine diagnostic work has to be limited. Introduction of mycological media in the routine examination of milk samples would surely lead to a decrease in the number of "sterile" samples. Therefore, an estimation of the incidence of mycotic mastitiscases in our country would be difficult, though it is probably less than 1 per cent. The steady increase in the use of antibiotics in therapy, as well as the continous low-level feeding of broad-spectrum antibiotics for the promotion of animal growth, are certainly factors which will intensify the problem of fungal disorders in animals.

Following the establishment of the diagnosis of mycotic mastitis there is the problem of treatment. In a great many cases medication with one or more of the common antibiotics will be started at the time of sampling, before the involvement of yeasts is recognised. As soon as it is recognised, the withdrawal of drugs of this kind is highly advisable according to the experience of many authors (4) (1). In vitro experiments demonstrate that the common antibiotics are not generally fungicidal (26) (11); on the contrary, some of them reveal a distinct growth-promoting effect on yeasts in vitro (15). Many in vivo observations also sup- 
port the idea that mycotic udder infections are intensified following medication with the common antibiotics (35) (14) (38) (17) (28) (33). It is also well established in human medicine that the use of antibiotics favours mycoses. There is no reason to doubt that similar considerations might apply to the bovine udder. Whether this is the result of the growth-stimulating effect seen in vitro or of some sort of lowering of the normal udder resistance is not clear. Probably an alteration of the normal bacterial flora of the udder is a factor of importance.

Iodides (4) (38) (35) (40), organic arsenic and mercurial preparations (26), quinoline derivatives (30), and dyes like gentian violet (4) are among remedies applied in mycotic mastitis with more or less effect. At present no fungicidal preparations adapted for intramammary use are known to be on the market. The newer antibiotics with antifungal activity, like nystatin, trichamycin and amphotericin $B$, have demonstrated clinical usefulness in fungal disorders in man. In vitro studies as well as the few experiments in vivo suggest that fungicides of this kind probably will be the future drugs of choice in the therapy of udder mycoses (4) (32).

\section{Acknowledgments}

We greatly appreciate the cooperation of the Department of Obstetrics and the Department of Surgery at the Veterinary College of Norway, and the Mastitis Laboratories in Stavanger and Trondheim. Thanks are also due to Mrs. Kreger-van Rij, Yeast Division, C.B.S., Delft, for examining the cultures from cases No. 1, 2, 4, 6 and 7. We are also greatly indebted to Dr. M. Ingram, Low Temperature Research Station, Cambridge, for his kind and valuable assistance.

\section{ADDENDUM}

Since this manuscript was submitted for publication four additional cases of acute mycotic mastitis have appeared. The causative agents of these were: Saccharomyces marxianus, Candida krusei, Candida tropicalis and a Trichosporon sp.

The cows on the farm on which the case caused by $S$. marxianus appeared, were fed brewery by-products, and the yeast was also isolated from the feed. In this connection it may be of interest that on a farm where brewery by-products were fed to the animals both $C$. krusei and S. marxianus could be isolated from the skin 
surfaces of several cows. There was no record of mycotic mastitis in this herd.

New experiments have also been performed to establish the effect of tetracyclines on the growth of yeasts. It was found, using sensitivity discs from another company, that the tetracyclines did not influence the growth of C.parapilosis, C.krusei or $S$. marxianus. The beneficial effect of tetracyclines on the growth observed with discs from the former company was presumably due to impurities.

In addition, pure culture tests in a fluid medium (Sabouraud glucose broth) with terramycin added up to $100 \mu \mathrm{g} / \mathrm{ml}$ showed no increase in growth as compared with the controls.

Some recent publications on the subject of mycotic mastitis have also come to our attention. Barbesier, J. (Arch. Inst. Past. Algér, 1958, 36, 12-14) isolated C. krusei from two quarters of a cow suffering from acute mastitis. Loken et al. (J. Amer. vet. med. Ass. 1959, 134, 401-403) described an outbreak of acute mastitis in 15 cows which had been treated with a penicillinstreptomycin mixture. The causative agent was identified as C. tropicalis.

Funke, H. (Nord. Vet.-Med. 1960, 12, 54-62) isolated yeasts from 21 samples of milk from abnormal quarters in 16 herds in the course of a two year period. The yeasts were classified as C. parapsilosis (7 strains), C. krusei (5), C.zeylanoides (1), C. pulcherrima (1), T.famata (1), T. sake (1), R. mucilagniosa (1) and 4 unidentified species.

The article by Walker, A. W., and Ayres, J. C. (Appl. Microbiol. 1959, 7, 251-255) may also be mentioned. Their results showed that none of the tetracyclines stimulated the growth in laboratory media of 39 yeast cultures of the genera Rhodotorula, Trichosporon, Torulopsis and Candida.

\section{REFERENCES}

1. Ainsworth, G. J. and P. V. C. Austwick: Vet. Rec. 1955, 67, 88.

2. Andersen, J. Blegvad and K. Leth Jørgensen: Nord. Vet.-Med. 1949, $1,958$.

3. Barron, Chr. N.: J. Amer. vet. med. Ass. 1955, $127,125$.

4. Beck, C. C.: MSU Vet. 1957, 17, 82.

5. Brown, C. Jr., S. Propp, M. C. Guest, R. T. Beebe. and L. Early: J. Amer. med. Ass. 1953, II, 206.

6. Carter, H. S. and J. L. Young: J. Path. Bact. 1950, 62, 271.

7. Cook, A. H.: The chemistry and biology of yeasts. Academic Press Inc. New York, 1958. 
8. Emmons, C. W.: Mycopathologia 1952, 6, 231.

9. Galli, G.: Vet. Ital. 1954, 5, 587.

10. Gerigh, K.: Uber das Vorkommen von Hefen und hefeähnlichen Organismen im Euter gesunder und mastitiskranker Kühe. Dissert. Inst. für Leb.hyg. d. Freien Univ. Berlin 1955.

11. Gioletti, G.: Atti Soc. It. Sc. Vet. 1956, 10, 636.

12. Harding, H. A. and J. K. Wilson: New York Agric. Exp. Sta. Techn. Bull. 1913, No. 27.

13. Hovmand, H. C., A. Jepsen and A. J. Overby: Nord. Vet.-Med. 1954, $6,591$.

14. Hulse, E. C.: Vet. Rec. 1952, 64, 210.

15. Huppert, M., D. A. MacPherson and J. Cazin: J. Bact. 1953, 65, 171.

16. Innes, J. R. M., H. R. Seibold and W. P. Arentzen: Amer. J. vet. Res. 1952, 13, 469.

17. Kauker, E.: Berl. Münch. Tierärztl. Wschr. 1955, 23, 407.

18. Klein, E.: J. Hyg. 1901, I, 78.

19. Kligman, A. M.: J. Amer. med. Ass. 1952, 149, II, 979.

20. Klimmer, M.: Proc. 11th Internat. Vet. Congress 1931, 3, 422, cited from Gerigh (10).

21. Lerche, M.: Berl. Münch. tierärztl. Wschr. 1952, 65, 64.

22. Lernau, C., A. Shapiro and M. Aschner: Refuah vet. 1947, 4, 37, cited from Gerigh (10).

23. Lodder, J. and N. J. W. Kreger-van Rij: The yeasts. North Holland Publ. Co. Amsterdam 1952.

24. McCarthy, R. T.: Vet. Med. 1956, 21, No. 12, 562.

25. Murphy, J. M. and C. H. Drake: Amer. J. vet. Res. 1947, 8, 43.

26. Pounden, W. D., J. M. Anderson and R. F. Jaeger: Amer. J. vet. Res. 1952, 13, 121.

27. Quin, A. H.: Vet. Med. 1955, 50, 301.

28. Redaelli, G.: Arch. Vet. Ital. 1957, 8, No. 1, 39.

29. Redaelli, G.: Arch. Vet. Ital. 1957, 8, No. 2, 97.

30. Rolle, M.: Dt.sch. tierärztl. Wschr. 1934, 42, 385.

31. Seele, W. und E. Lauer: Monatsheft. f. Tierh. k. 1955, 7, 94.

32. Ségretain, G., J. Verge,, H. Drieux, E. Mariat, A. Paraf, C. Labie and $B$. Thérou: Bull. Acad. vet. Fr. 1956, 29, 31.

33. Simon, J. and R. Hall: J. Milk and Food Tech. 1955, 18, 298.

34. Simon, J., R. E. Nichols and E. V. Morse: J. Amer. vet. med. Ass. $1953,122,31$.

35. Steele-Bodger, A.: Vet. Rec. 1953, 65, 304.

36. Stuart, P.: Vet. Rec. 1951, 63, 314.

37. Torack, R. M.: Amer. J. Med. 1957, 22, 872.

38. Trujillo, B., A. J. Borrel and C. Oger: Rev. Méd. vét. 1955, 106, 586.

39. Trüper, E.: Milchwirtsch. Forschungen 1928, 6, 351.

40. Tucker, E. W.: Cornell Vet. 1954, 44, 79.

\section{SUMMARY}

A survey is given of the literature concerning yeast mastitis in cows. Routine mycological examinations of 980 milk samples from clinically normal quarters indicated that yeasts do not belong to the 
normal microflora of the udder. 5 cases of mycotic infections were found in 480 samples from abnormal quarters. A description is given of a total of 7 cases of udder infections from which the following agents were isolated: Saccharomyces marxianus, Saccharomyces fragilis, Candida krusei, Candida parapsilosis var. intermedia and a Trichosporon sp.

Experimental infection of cows with 2 of the isolated strains produced distinct local and general symptoms. In vitro sensitivity tests revealed no effect of penicillin, streptomycin, chloramphenicol, aureomycin and terramycin on any of the mastitis strains. The 2 latter antibiotics showed a marked growth-stimulating effect. Polymyxin B, nystatin and trichamycin proved to have an effect on all strains.

A list of yeast species reported from mastitis cases demonstrates the rich variety of agents implied, the habitats and the pathogenic properties of which are discussed. Attention is called to the rôle of the extensive use of antibiotics as a factor explaining the increasing number of mycotic mastitis.

\section{ZUSAMMENFASSUNG \\ Bovine mykotische Mastitis.}

Es wird eine Literaturübersicht über Hefepilzmastitiden bei der Kuh gegeben. Routinemässige mykologische Untersuchungen von 980 Zitzenproben klinisch normaler Drüsen scheinen darzulegen, dass Hefepilze nicht zur normalen Mikroflora des Euters gehören. In 480 Proben von abnormen Drüsen wurden 5 Fälle von Pilzinfektionen ermittelt. Insgesamt werden 7 Fälle von Euterinfektionen beschrieben, von denen folgende Organismen isoliert werden: Saccharomyces marxianus, Saccharomyces fragilis, Candida krusei, Candida parapsilosis var. intermedia und ein Trichosporon sp.

Eine experimentelle Infektion von Kühen mit 2 der isolierten Stämme gab deutliche lokale und allgemeine Symptome. Bei Sensitivitätsversuchen in vitro mit den isolierten Mastitisstämmen wurde kein Effekt von Penicillin, Streptomycin, Chloramphenicol, Aureomycin und Terramycin festgestellt. Die beiden letztgenannten zeigten eine deutliche wachtumsstimulierende Wirkung. Polymyxin B, Nystatin und Trichamycin ergaben Wirkung auf alle Stämme.

Ein Verzeichnis über Hefepilzstämme von Mastitiden zeigt die grosse Variation in implizierten Organismen, deren naturliches Reservoir und pathogene Eigenschaften besprochen werden. Es wird die Aufmerksamkeit auf die Bedeutung gelenkt, die ein ausgestreckter Gebrauch von Antibiotika haben kann in bezug auf die steigende Anzahl von Pilzmastitiden.

SAMMENDRAG

Gjærsoppmastitter hos $k u$.

Det er gitt en oversikt over litteratur om gjærsoppmastitter hos ku. Rutinemessige mykologiske unders $\varnothing$ kelser av 980 spenepr $\varnothing$ ver fra klinisk normale kjertler syntes å vise at gjærsopp ikke hører til den 
normale mikroflora i jur. Det ble funnet 5 tilfelle av soppinfeksjoner i 480 prøver fra abnorme kjertler. Det er gitt en beskrivelse av i alt 7 tilfelle av jurinfeksjoner, fra hvilke følgende organismer ble isolert: Saccharomyces marxianus, Saccharomyces fragilis, Candida krusei, Candida parapsilosis var. intermedia og en Trichosporon sp.

Eksperimentell infeksjon av kuer med 2 av de isolerte stammer gav tydelige lokale og generelle symptomer. Ved in vitro sensitivitetsfors $\varnothing \mathrm{k}$ med de isolerte mastitisstammer fantes ingen effekt av penicillin, streptomycin, chloramphenicol, aureomycin og terramycin. De 2 sistnevnte viste en tydelig vekst-stimulerende virkning. Polymyxin B, nystatin og trichamycin gav girkning på alle stammer.

En fortegnelse over gjærsoppstammer fra mastitter viser den store variasjon i impliserte organismer, hvis naturlige reservoir og patogene egenskaper er omtalt. Man gjør oppmerksom på den betydning utstrakt bruk av antibiotika kan ha når det gjelder det $\emptyset$ kende antall av soppmastitter.

(Received March 15. 1959). 